\title{
Covid-19: four fifths of cases are asymptomatic, China figures indicate
}

\author{
Michael Day
}

London

New evidence has emerged from China indicating that the large majority of coronavirus infections do not result in symptoms.

Chinese authorities began publishing daily figures on 1 April on the number of new coronavirus cases that are asymptomatic, with the first day's figures suggesting that around four in five coronavirus infections caused no illness. Many experts believe that unnoticed, asymptomatic cases of coronavirus infection could be an important source of contagion.

A total of 130 of 166 new infections (78\%) identified in the 24 hours to the afternoon of Wednesday 1 April were asymptomatic, said China's National Health Commission. And most of the 36 cases in which patients showed symptoms involved arrivals from overseas, down from 48 the previous day, the commission said.

China is rigorously testing arrivals from overseas for fear of importing a fresh outbreak of covid- 19 .

Tom Jefferson, an epidemiologist and honorary research fellow at the Centre for Evidence-Based Medicine at the University of Oxford, said the findings were "very, very important." He told The BMJ, "The sample is small, and more data will become available. Also, it's not clear exactly how these cases were identified. But let's just say they are generalisable. And even if they are $10 \%$ out, then this suggests the virus is everywhere. If - and I stress, if - the results are representative, then we have to ask, "What the hell are we locking down for?"'

Jefferson said that it was quite likely that the virus had been circulating for longer than generally believed and that large swathes of the population had already been exposed.

Users of Chinese social media have expressed fears that carriers with no symptoms could be spreading the virus unknowingly, especially now that infections have subsided and authorities have eased curbs on travel for people in previous hotspots in the epidemic.

Zhong Nanshan, a senior medical adviser to the Chinese government, said that asymptomatic infections would not be able to cause another major outbreak of covid-19 if such people were kept in isolation. Officials have said this is usually for 14 days.
Nanshan said that once asymptomatic infected people were identified, they and their contacts would be isolated and kept under observation.

Citing classified data, the South China Morning Post said that China had already found more than 43000 cases of asymptomatic infection through contact tracing.

The latest findings seem to contradict a World Health Organization report in February that was based on covid-19 in China. This suggested that "the proportion of truly asymptomatic infections is unclear but appears to be relatively rare and does not appear to be a major driver of transmission."

But since that WHO report other researchers, including Sergio Romagnani, a professor of clinical immunology at the University of Florence, have said they have evidence that most people infected by the virus do not show symptoms. Romagnani led the research that showed that blanket testing in a completely isolated village of roughly 3000 people in northern Italy saw the number of people with covid- 19 symptoms fall by over $90 \%$ within 10 days by isolating people who were symptomatic and those who were asymptomatic. ${ }^{2}$

In an article on the website of the Centre for Evidence-Based Medicine, Jefferson and Carl Heneghan, director of the centre and editor of $B M J E B M$, write, "There can be little doubt that covid-19 may be far more widely distributed than some may believe. Lockdown is going to bankrupt all of us and our descendants and is unlikely at this point to slow or halt viral circulation as the genie is out of the bottle.

"What the current situation boils down to is this: is economic meltdown a price worth paying to halt or delay what is already amongst us?"”

World Health Organization. Report of the WHO-China Joint Mission on coronavirus disease 2019 (COVID-19). 2020. https://www.who.int/docs/default-source/coronaviruse/who-chinajoint-mission-on-covid-19-final-report.pdf.

2 Day M. Covid-19: identifying and isolating asymptomatic people helped eliminate virus in Italian village. BMJ 2020;368:m1165. 10.1136/bmi.m1165 32205334

3 Jefferson T, Hennegan C. Covid-19-The tipping point? Mar 2020. Centre for

Evidence-Based Medicine. Mar 2020. https://www.cebm.net/2020/03/covid-19-the-tippingpoint.

Published by the BMJ Publishing Group Limited. For permission to use (where not already granted under a licence) please go to http://group.bmj.com/group/rights-licensing/ permissions 